\section{To: (Receiving Organization) DISTRIBUTION}

5. Proj./Prog./Dept./Div.: Spent Nuclear Fuel Project 8. Originator Remarks: For Release

11. Receiver Remarks

11A. Design Basel ine Document? [] Yes [X] No

3. From: (Originating organization) SNF Storage Projects

6. Design Authority/ Design Agent/Cog. Engr.:

K. E. Smith

[x] No

4. Related EDT Ho.:

$N / A$

7. Purchase Order No.:

N/A

9. Equip./Component Ho.:

$N / A$

10. System/Bldg./Facility:

$N / A$

12. Major Assm. Dwg. No.:

MCO

13. Permit/Permit Application Ho.: $N / A$

14. Required Response Date: $N / A$

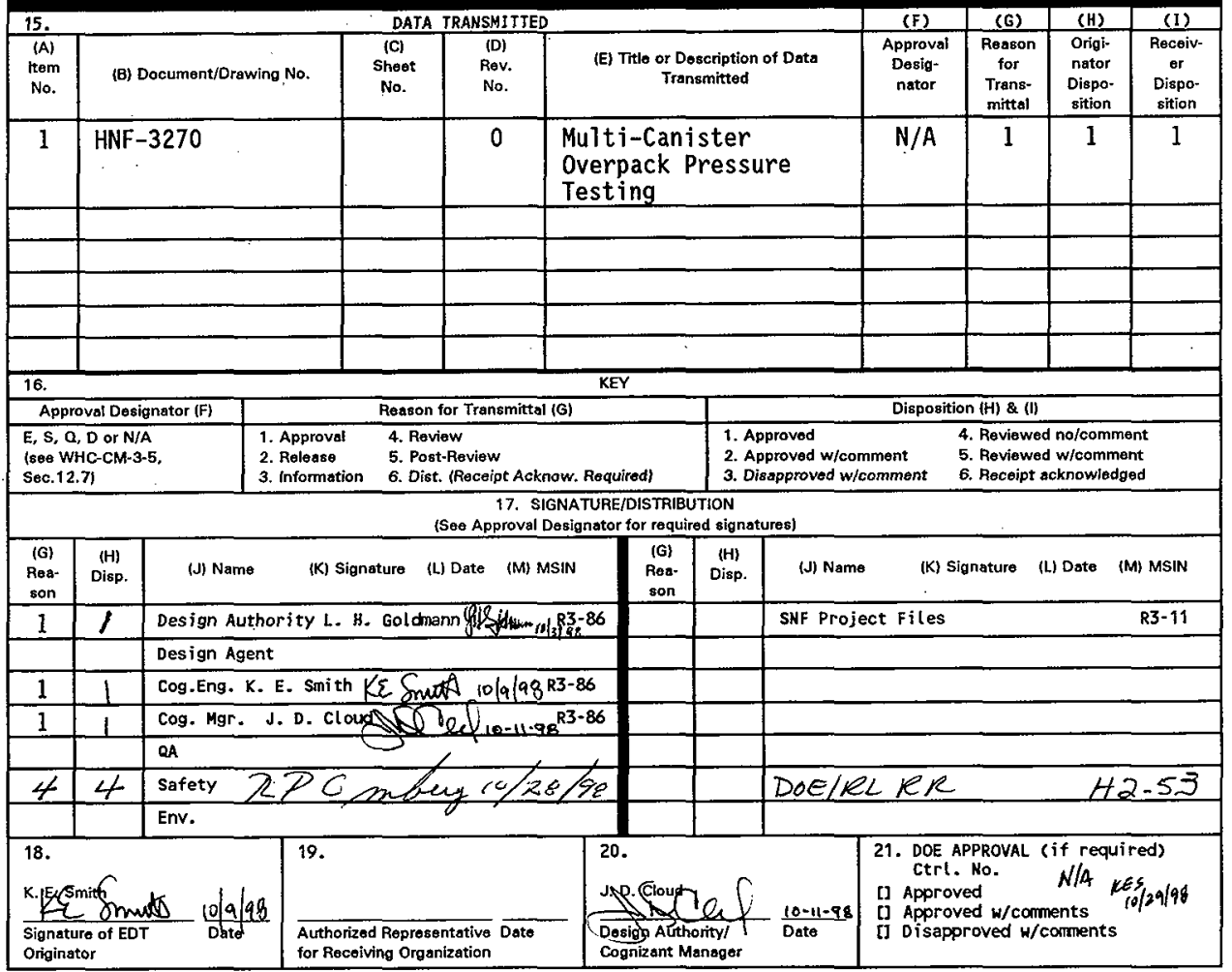




\title{
Multi-Canister Overpack Pressure Testing
}

\author{
K. E. Smith
}

DE\&S Hanford, Inc., Richland, WA 99352

U.S. Department of Energy Contract DE-AC06-96RL.13200

$\begin{array}{lll}\text { EDT/ECN: } & 625785 & \text { UC: } 600 \\ \text { Org Code: } & 2 T 340 & \text { Charge Code: } 105532 / \text { AA30 } \\ \text { B\&R Code: } & \text { EW7040000 } & \text { Total Pages: } 5\end{array}$

Key Words: MCO, Spent Fue1, Packaging, Container, Issue, Hydrostatic Test

Abstract: The Multi-Canister Overpack (MCO) shield plug closure assembly will be hydrostatically tested at the fabricator's shop to the 150 psig design test requirement in accordance with the ASME Code. Additionally, the MCO shell and collar will be hydrostatically tested at the fabricator's shop to the 450 psig design test requirement.

Commerical practice has not required a pressure test of the closure weld after spent fuel is loaded in the containers. Based on this precedent and Code Case N-595-1, the MCO closure weld will not be pressure tested in the field.

TRADEMARK DISCLAIMER. Reference herein to any specific commercial product, process, or service by trade name, trademark, manufacturer, or otherwise, does not necessarily constitute or imply its endorsement, recommendation, or favoring by the Uni ted States Government or any agency thereof or its contractors or subcontractors.

Printed in the United States of America. To obtain copies of this document, contact: Document Control Services, P.O. Box 950, Mailstop H6-08, Richland WA 99352, Phone (509) 372-2420; Fax (509) 376-4989.
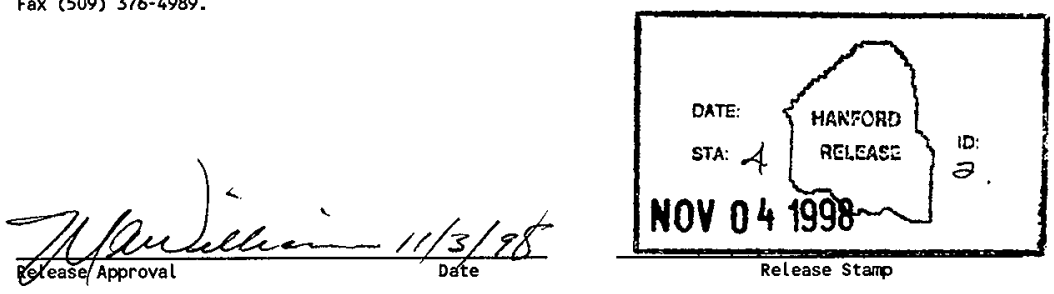

\section{Approved for Public Release}




\section{Issue Closure Package}

Issue: MCO Pressure Testing

Lead:

K. E. Smith

KE Smet $10 / 9 / 98$

MCO Implementation

Manager, DE\&S Hanford

\section{Approvals:}

Chief Engineer:

A. M. Segrest

DE\&S Hanford

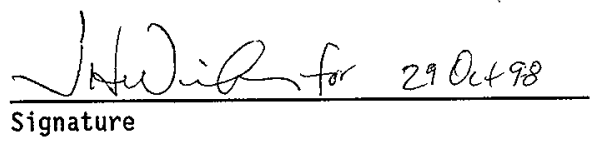

Technical Operations:

J. A. Swenson

Manager

DE\&S Hanford

Construction Projects:

A. R. Hollins

Manager

DE\&S Hanford

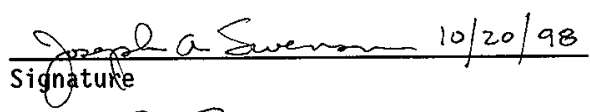

Nuclear Safety:

Robert G. Morgan

Manager

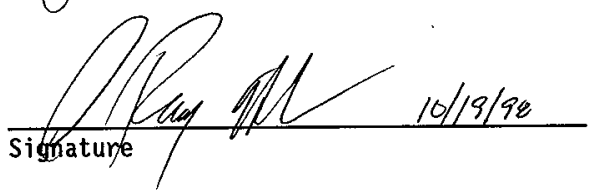

DE\&S Hanford

MCO Design Authority:

L. H. Goldmann

DE\&S Hanford

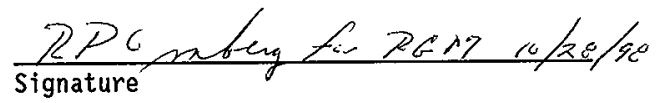

$\frac{\text { gunothetdmon } 10 / 9 / 98}{\text { Signature }}$ 
HNF-3270, Rev. 0

MULTI-CANISTER OVERPACK

PRESSURE TESTING

\section{Introduction}

The American Society of Mechanical Engineers (ASME) Boiler and Pressure Vessel code requires pressure testing of each vessel prior to placement in service. The Multi-Canister Overpack (MCO) design is a split pressure rated container with the design rating of the shield plug closure system at 150 psig minimum and the MCO shell and welded cover cap over the shield plug assembly at 450 psig. This split pressure rating causes some difficulty in meeting Code pressure test requirements because the MCO will not be assembled in the 450 psig configuration until the MCO is loaded with spent nuclear fuel and the cover cap is welded in place. The purpose of this paper is to document the pressure testing to be performed on the MCO to demonstrate compliance with the ASME Code. Specific methods to be employed to conduct the tests will be documented in the MCO Fabrication Specification.

\section{Discussion}

\section{A. Pressure Testing at the Fabricator's Shop}

Section NB-6110 "Pressure Testing of Components, Appurtenances, and Systems" and NB-6200 "Hydrostatic Tests" of the ASME Code require vessels to be hydrostatically tested to a pressure of no less than 1.25 times the design pressure. During pressure testing, stresses are allowed to be higher than the stresses used during normal operations, but not so high as to result in permanent deformation of the vessel. Vessels undergoing pressure testing are expected to fully endure the test and be fully suitable for service after the test. The split pressure rating of the MCO poses some difficulty in that the collar thread region of the shield plug closure system is rated at $150 \mathrm{psig}$ and is not designed to withstand the stresses induced by a pressure test associated with the $450 \mathrm{psig}$ design rating.

At the fabricator's shop, the shield plug closure assembly will be hydrostatically tested, at a minimum, to the $150 \mathrm{psig}$ design test requirement. The MCO shell and collar will be hydrostatically tested at the 450 psig design test requirement. One method to pressure test the MCO shell and collar to the fu11 450 psig design requirement involves fabricating a special test plug as shown in the attached conceptual sketch. The plug is held into the shell structure utilizing a portion of the buttress threads of the MCO collar and seals to the top inside surface of the collar. This permits as much pressure testing as possible of the MCO collar and assures the bulk of the collar material is fully hydrostatically tested. Since the test plug only engages a portion of the threads and does not preload the collar threads as does the locking ring/shield plug combination, the collar thread region is not overstressed at the higher test pressure. An alternative method to test the 
HNF-3270, Rev. 0

shell and collar to the higher test pressure with the shield plug assembly in place involves restraining the outside circumference of the collar to preclude any deformation. The ultimate method used to perform the pressure test of the shell and collar will be reflected in the MCO Fabrication Specification.

\section{B. Pressure Testing After Cover Cap Welding}

After welding the cover cap over the shield plug closure assembly, the MCO configuration will be consistent with the 450 psig design rating. However, in commercial practice, nuclear fuel containers are not pressure tested after the fuel is placed into the container. A hydrostatic test of the welded cover cap is not an option as water is not permitted in the facility and introduction of water to the MCO is prohibited at that time. While a pneumatic test of the installed cover cap would not necessarily pressurize the volume of the MCO containing the fuel, there is no assurance that the mechanical seal would hold in the reverse direction to the $450 \mathrm{psig}$ design test requirement. If the sea 1 were to leak, the entire vesse] would be pressurized, introducing risk of contamination and exposure to workers. Additionally, the inherent danger of pneumatic testing makes it an undesirable test method.

The aforementioned difficulties in pressure testing loaded spent fuel containers have resulted in the drafting of Code Case N-595-1 for SNF storage canisters (Reference 1), currently pending approval by the ASME Committee, which specifically exempts the final closure welds of SNF canisters from the pressure test requirements of the code. To ensure weld quality, the Code Case requires a multiple pass dye penetrant weld examination and helium leak testing of final closure welds. Based on this Code Case, the MCO closure weld will not be pressure tested; however, multiple weld passes will be examined with dye penetrant and a helium leakage rate test will be performed.

\section{Conclusion}

The MCO shield plug closure assembly will be hydrostatically tested at the fabricator's shop to the $150 \mathrm{psig}$ design test requirement, as a minimum, in accordance with the ASME Code. Additionally, the MCO shell and collar will be hydrostatically tested at the fabricator's shop to the 450 psig design test requirement. Commerical practice has not required a pressure test of the closure weld after spent fuel is loaded in the containers. Based on this precedent and Code Case $\mathrm{N}-595$, the $\mathrm{MCO}$ closure weld wi.ll not be pressure tested in the field.

\section{References}

1. ASME Code Case N-595-1 for Spent Fuel Storage Canisters 
HNF-3270, Rev. O

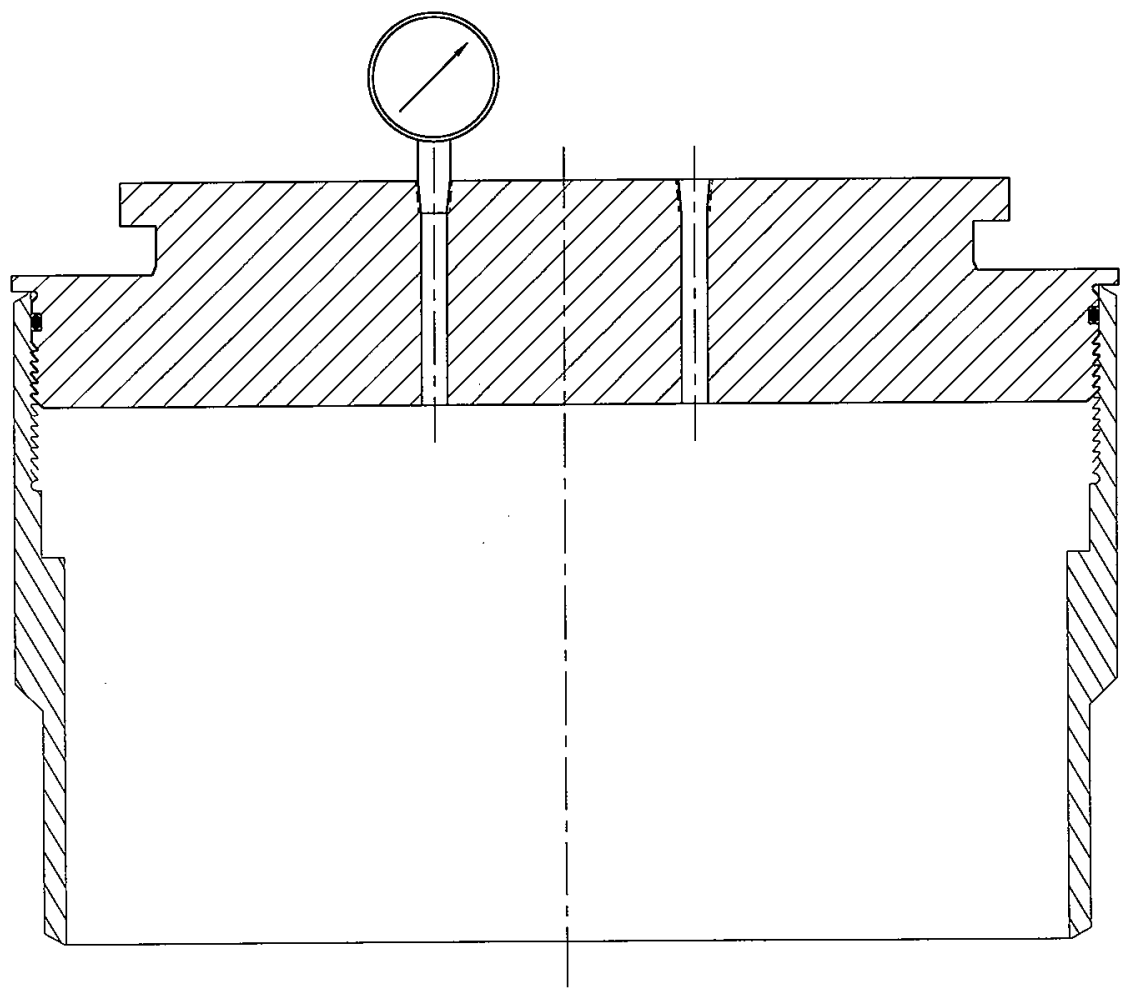

CADFILE: LOU-CAP.OWG

4 


\section{DISTRIBUTION COVERSHEET}

Subject: MCO ISSUE PAPERS PER ATTACHED DISTRIBUTION INDEX

\section{DISTRIBUTION}

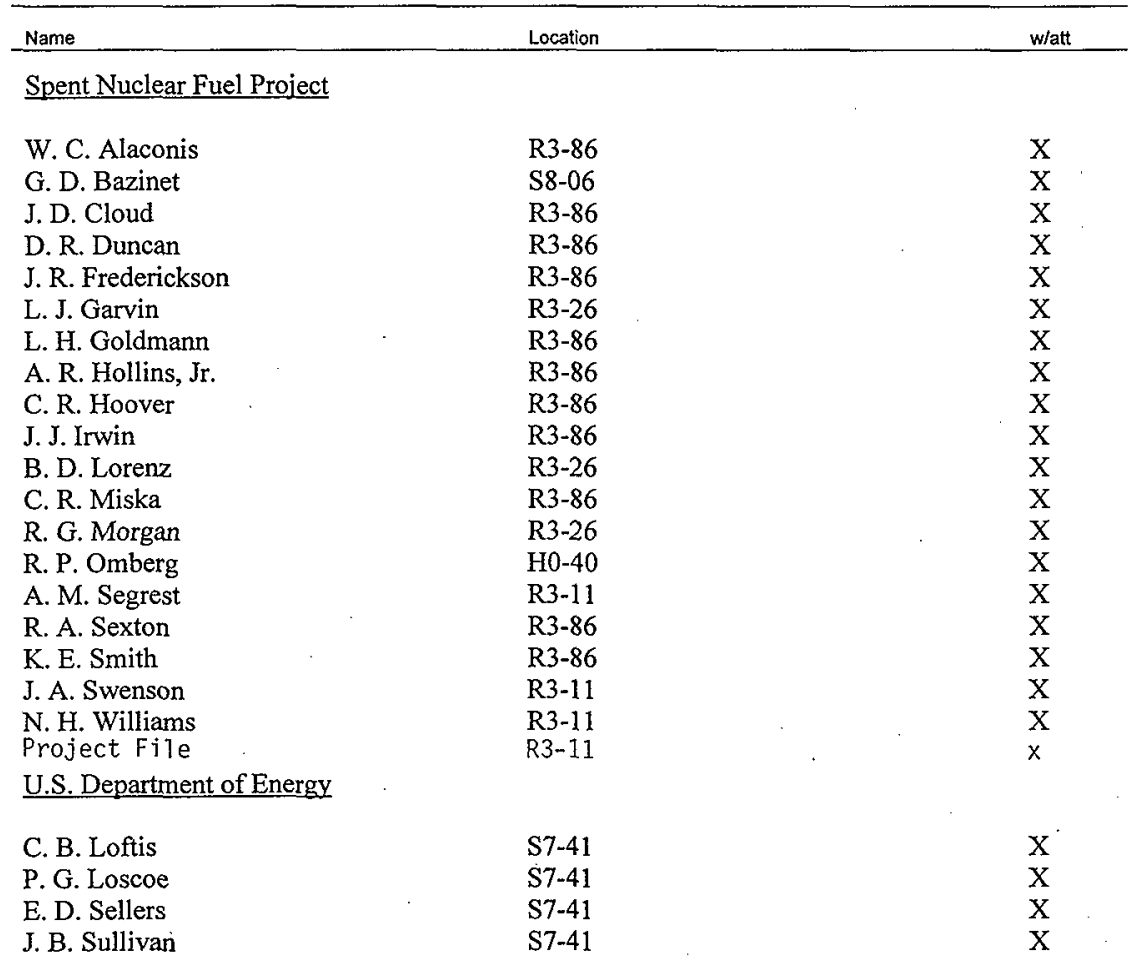




\section{DISTRIBUTION INDEX}

The Multi-Canister Overpack Issue papers listed below are being distributed as a package to facilitate future reference and use by SNF Project personnel. The following issue papers are attached:

1. HNF-2876, Oxygen Gettering Issue Closure Package

2. HNF-3265, MCO Number of Shield Plug Ports

3. HNF-3399, MCO Necessity of the Rupture Disk

4. HNF-3267, MCO Dual Pressure Rating

5. HNF-3293, MCO Ultrasonic Examination of Closure Weld

6. HNF-3354, MCO Monitoring Issue Closure Package and HNF-3312, MCO

Monitoring Activity Description

7. HNF-3292, MCO Sealing Configuration

8. HNF-3266, MCO Design Pressure Rating

9. HNF-3255, ASME Code Requirements for MCO Design and Fabrication

10. HNF-3398, MCO Inservice Inspection and Maintenance

11. HNF-3420, MCO Internal HEPA Filters

12. HNF-3036, Low Reactive Surface Area Issue Closure Package

13. HNF-3270, MCO Pressure Testing 